\title{
Investigating Factors Influencing Learners Placed at Save-Our-Soul Villages to Become Street Kids
}

\author{
Dr Thulani E. Mhlongo, PhD \\ University of Johannesburg \\ South African Council of educators \\ South Africa \\ Prof Debeila J.R \\ School of Postgraduate Studies \\ University of South Africa \\ South Africa
}

\begin{abstract}
Botswana like many other countries worldwide encounters challenges of vulnerable children that are strategically placed at Save-Our-Soul (SOS) Children's Villages where they are supposed to be safe and happy because they receive day care, education and medical assistance. Unfortunately, many of the kids placed at SOS villages become "run-away kids". The main focus of this article is to report on findings of a qualitative research project that was conducted among purposefully selected stakeholders to determine why vulnerable learners placed at SOS villages become "run-away kids" (street kids).

In addition to the use of interviews coupled with observation and reflective notes, the researchers also applied the Mmogo-method which is a projective research technique used in psychological projections. Mmogo projections allow unconscious meanings to emerge from the participants' reflections on their sense of belonging. Thus, the researchers were able to access and clarify the symbolism behind the visual representations within the participants' cultural context.

An analysis of qualitatively derived data revealed a myriad of factors that triggers learners placed at SOS children's villages to become "run-away-kids". Among other problems one main problem is that they believe that the SOS village and community failed them by not giving them the necessary freedom that they want. They think that they are better off without the help of anybody. To alleviate their fears it is recommended that parents need to establish a positive communicative medium that would allow both the affected child and the parent to fully communicate with each other while at the SOS village and beyond.
\end{abstract}

Keywords: Factors, vulnerable learners, Save-Our-Soul villages, street kids

\section{Introduction and rationale}

Botswana like many countries globally has to deal with the challenges of vulnerable children. There are different factors contributing to the vulnerability of these children, such as being raised in an orphanage, abandoned by parents, child abuse, being dumped by mothers immediately after birth, chased away from home due to fights as well as neglect by parents. Some of these children are strategically placed at SOS Children's Villages. It is assumed that since they are accommodated in supervised shelters they are safe and happy. However, their tendency to run away to the streets serves as an indication that they are unhappy and can thus be said to be at-risk and not out of harm's way. The focus of this article is to report on research findings of a project that was conducted to find out what triggers them to become street kids.

The Children's Act $(2004 ; 5)$ is meant to make provision for promotion of protection and care of the child; for the promotion of the physical, emotional, intellectual, social development and general well-being of children; for the establishment of structures to provide for the care, support, protection and rehabilitation of children; and for matters connected therewith. This is supported by the Children in need of Care Regulations (2005:195) that an institution shall safeguard and promote the welfare of each child who is under its care. 
Without prejudice to the generality of sub regulations, the institution shall provide food, clothing, health, and education, emotional, psychological intellectual, social and spiritual support for the needs of each child under its care, in accordance with the order of the children's court and protect the child from abuse, exploitation, neglect and discrimination.

According to Watts (2001), in 1980 SOS Children's Village Association of Botswana was founded. Subsequently, three SOS villages were strategically located at Serowe, Tlokweng and Francistown. At these villages children are provided with day care, education and medical assistance. Essentially, these villages are meant to care for orphaned, destitute, abandoned, neglected and abused children who like other children have to be developed into responsible and independent adults who can cope with the challenges of the future. Komane (2001) outlines that SOS is based on four principles namely; the mother, each child has a caring parent, brother and sisters, family ties grow naturally, the house, each family creates its own home and the village, SOS family is a part of the community that creates opportunities for children to grow up in a natural environment.

Historically, SOS Children's villages provided accommodation only for learners with different problems. They were supposed to be trained in life skills useful to the society. These learners are educated in the most restrictive environments because they are segregated from their peers. It was only in 2004 that the Botswana Government developed its first policy in the Children's Act. The policy promoted two pillars of vision 2016, which advocates that by 2016 Botswana should have a secure, safe, educated and informed nation.

\section{Statement of the problem}

The aim of Botswana's Constitution is to produce a society that respects and values diversity amongst its citizens. It is therefore advocated by the Ministry of Home Affairs and the government in general, that every child has the right to life, health, shelter, clothing, education, food and so forth. In this context, the Children's Act (2004:5) views a child as a person who is less than 18 years old. It continues to state that children's rights of physical, emotional, intellectual and social development should be promoted and protected. They should be protected against harm such as ill-treatment and sexual abuse. Most of the children who stay in SOS children's village are less than 18 years old which shows that they are still minors and they do not qualify to vote as the Constitution of Botswana (2007:38) indicates that a person shall qualify to vote only when he or she is a citizen of Botswana and has attained the age of 18 years old.

SOS Children's Village is meant to protect vulnerable children from harm but, surprisingly, learners under the age of 18 years placed at SOS children's villages run away to the streets where they become exposed to all forms of physical, emotional and psychological harm (Adebiyi, Owoaje and Asuzu, 2008:48). As early as 1999, Barrette, as cited by Kariuki (1999: 20) indicated that all these primary and secondary causes interact and influence one another in a complicated way and it is not easy to deal with one factor without touching on the others because they do not exist in isolation. Some of the children fall pregnant; indulge in promiscuous behaviors, drug abuse, theft and related forms of indiscipline. As little research has been done in this area, the researchers therefore found it necessary to investigate further on why learners placed at the SOS children`s village become street children.

\section{Research questions}

In the light of the foregoing exposition, the urgent question is important?

What contributory factors influence learners placed at the SOS villages to become street kids?

\section{Sub-question}

To answer the question above this sub-question was also posed;

- What intervention strategies can be implemented to retain vulnerable learners in the SOS Children`s village?

\section{Aim of the Article}

The aim of this article is to report on the findings of a research project, the purpose of which was to investigate the factors that influence learners placed at the SOS Children's Village in Francistown to become street kids.

\section{Sub-aim}

In order to achieve the above aim this sub - aim must also be achieved:

- To report on the intervention strategies that were found to be key to retain the learners in the SOS Children's Villages in Francistown (Botswana). 


\section{Significance of the Report}

Parties that will benefit from this report are educators, learners, Education departments, Non-Governmental Organizations (NGOs), Ministry of Education and Skills, researchers, university students and the community at large. Educators will benefit from the report as its aim is to increase an awareness of the basic factors that trigger vulnerable learners placed at the SOS Villages to become street kids. It will also be easy for educators to assist vulnerable learners appropriately.

The Ministry of Education may use the results of this report when selecting In-service courses that they intend to offer to educators. The Department of Education will benefit in the sense that they provide the type of assessments and assistance that would be most appropriate for the different learners. They will also be able to empower their employees with relevant skills on how to deal with the learners. After this report the NGO's, as the donors of the SOS Villages, will have a clear picture of what is happening at SOS centers. The results will assist them to find out whether their donations are properly utilized. Other researchers will also benefit from the results of this report as they may use these results as a reference when doing their own projects. The study will also provide information about SOS Children's Village to university students in other parts of the world. As for the community, this study will be useful because they will be provided with the knowledge about the SOS villages and how to manage programs for run-away kids.

\section{Theoretical framework of the report}

Since every study of this nature has to be underpinned by a philosophical stance, this research project was underpinned by the dictates of the Botswana Children's Act 28 of 2004 which promulgated that every child as a psycho-physical-noetic being should be cared for and protected against all forms of physical, psychological, mental and spiritual harm. In 1980 SOS Children's village association of Botswana was established and subsequently, SOS children's villages were established. The purpose of SOS children's villages was to care for atrisk children in order to empower them to develop into responsible adults who can cope with life's challenges. This theory of social class empowerment was further operationalized in 2004 when Botswana developed a fully defined policy in the Children's Act which promoted one of vision 2016 pillars which advocates a secure and safe nation.

\section{Literature review}

The phenomenon "street kids" has been variously defined. According to Kariuki (1999:11), the concept "street children" is in fact a catch word, meaning that it is a misnomer that centers our attention only on one aspect of an individual's troubles, such as his lack of residence or housing, whereas in reality, a street child is out of formal schooling, has no function, no role within the community and he generally has few if any social supports. These children are in fact jobless, penniless, functionless and support-less as well as homeless. Brown (1993:17) suggests that these children confidently leave home with the hope of finding a creative solution to their problems. Once they are on the streets, they develop a repertoire of coping strategies, and generally cope successfully with the demands of street life. But nevertheless, life on the streets can have intense effects on the child. The typical street child is known to be impulsive, unrealistic, unable to talk about memories of life at home especially as she/he has no contact with her/his family, and is not attending school.Therefore, street children can be thought of as children found living in the street for many reasons including having difficult social situations at home, unemployment, alcoholism, violence and abuse. A comprehensive definition of street children must look at the different groups of children who live on/or off the street, for which the street plays a defining role. For example the following factors play a role:

- Children who live on the street who don't have parents: These are children who ran away from their families and live alone on the streets;

- Children who work on the street during the day but sleep at home during the night: These are children who spend most of their time on the streets fending for themselves but returning home on regular basis;

- Children who live on the street together with their family: these are children from street families;

- Children who move between the home, the street and institutions;

- Children who live on the street periodically; and

- Children who are traveling (between cities and countries). 
Once on the street, children quickly become victims of drugs, commercial sexual exploitation, and crime. They lose contact with school and other societal institutions. They sniff glue or other illicit and dangerous substances. All have health problems such as malnutrition, skin diseases, gastrointestinal disorders and TB. Such pervasive threats to mental and physical welfare pose big challenges when rehabilitating these children to a healthy and meaningful life.

Although the phenomenon of street children is differently defined, all street kids have similarities. There is agreement that children no longer trust themselves in the hands of society, hence they have taken full control of their lives to manage their lives and future. According to Ross (1991), when children abandon or are abandoned by family or community and gravitate to the street, the child's physical, emotional and educational needs are not met. With their basic needs not met, street children are compelled to try and skim off a very small share of the wealth found in white urban areas through car washing and parking, begging, odd-jobbing, scavenging, and in some cases, through prostitution and petty crime simply to survive from day to day. Thus, they become children of the streets by necessity, not by choice. Since these children are in an anti-child culture, they become vulnerable to exploitation, (Raffaelli 1996, Sptekar 1988, Adams et al. 1985).

The researcher reasons that this phenomenon of street children is a growing problem in South Africa, and increased teen homelessness may also have been stimulated by greater societal tolerance regarding the homeless condition and way of life in major cities. Current social services are uncoordinated and fragmented. This becomes a major impediment in efforts to help children, who have multiple needs, as is characteristic of all homeless, runaway or expelled-from-home. Current research shows a trend toward long-term homelessness for runaway adolescents. Furthermore, the majorities of these children come from dysfunctional families and are in a desperate need for positive social skills (Vogel.2001:229-248).

\section{Save- Our- Soul (SOS) village}

Swift (2007) indicates that SOS village is the world's largest charity Children's Village for orphaned and abandoned children. This is supported by the Children in need of care regulations (2005:195) that SOS village is an independent, non-governmental and social development organization, which has been active in the field of children's needs, concerns and rights since 1949. Its activities focus on orphans, neglected or abandoned children as well as disadvantaged learners.

\section{Research design and methodology}

The research project was based on a critical narrative research design which served as an overall plan of the whole study (Berk, 2005:16). Since the researchers were concerned with understanding the in-depth views and perceptions of the participants, a qualitative research paradigm was adopted. This approach is supported by Bell (2005:58). The researchers chose this approach because it prompted the participants to discuss their views indepth. This enabled the researchers to elicit more information from the participants so that they can provide deeper information about the topic under study. A narrative approach was chosen as the research design in both data collection and analysis processes (Leedy \& Ormrod, 2001; Leedy and Ormrod, 2005: 91). Narratives allowed the researchers to access the learners' experiences at SOS villages as well as the management perceptions on the learners` experiences (Eatough \& Smith, 2008; Murray, Davidson \& Schweitzer, 2008).The participants narrated their stories while the researchers constructed and integrated narratives of their experiences (Creswell, 2007). The narratives were then reframed and reconstructed for personal exploration and collective interpretation of the psycho-educational implications (Hiles \& Cermak, 2008).

\subsection{Tools for data collection and or/data generation}

In-depth interviews with the learners using Mmogo method and observation techniques were used for data collection. Moreover, focus group interviews with the teachers and parents were also employed to collect data (Marvista, 2004:56). In the in-depth focus group, the participants were provided with malleable clay, beads and straws and they were requested to do the following:

Think about your life before you come to SOS Children's Village. Think about your life in SOS Children's Village. What is happening? How didyou feel before you got there? What came into your mind while there? How did your stay at SOS affect your life style? Express all your answers with a visual presentation or picture using the objects before you.The participants were given time to complete their visual presentations. Video recordings were taken during the building of the models and after the models had been completed to help ensure the trustworthiness of the findings. 
The representations were also photographed to ensure accuracy during the analysis of the data. The explanations of each visual representation were digitally recorded and transcribed. Each member of the group was asked follow-up questions as a means of gleaning information about the different models and these follow-up questions were asked after the participants completed the presentations:

What did you make? What influenced you to create this schematic representation?

Each participant described his own visual representation and then the other participants were asked to verify if they also went through similar experiences, to add to or modify the narrations. This enabled the researcher to gain an understanding of their perceptions and to clarify indispensable information given by the participants and, at the same time, link and find meanings with their feelings to the models and their verbal interpretations of the models.

The Mmogo-method is a projective research technique used in psychological projections that allow unconscious meanings to emerge from the participants' reflections on their sense of belonging (Roos, 2012: 76). The researcher was able to access and clarify the symbolism behind the visual representations within the participants' cultural context. The researcher also analyzed guidance teacher's records, the school log book, the SOS children's village policy and the social worker's records in the school at the SOS village to find out more about the behavior of the learners during their stay at the SOS centers.

Furthermore, observation technique was used as a way of gathering data by watching behavior and noting observable feelings of the participants.This enabled the researcher to gain an in-depth understanding of their psychological being which would not be revealed through verbal expressions (Atkinson \& Harmmersely, 2000). Field notes taken during the data collation phase were summarized in a reflective journal to gain a deeper understanding of the narratives, and a video recorder was used so that the data could be explored intensively.

\subsection{Study population and sampling}

As it is not possible to study the entire population, the research focused on the narrations of 20 purposively selected participants based on experience and longevity of service at the SOS villages which availed better interaction with the vulnerable learners. As such, 4 boys and 4 girls; 3 mothers; 3 Guidance Teachers; 2 school heads; 1 social worker; 1 nurse; 1 head of institution and 1 SOS educator were selected. This sample was able to communicate in Setswana or English. In this context, it is obvious that the sample consisted of 20 participants selected from the entire population.This sample is defined by Marvasti (2004:15) as a sub- group of the population to which the results could be generalized.

\subsection{Data analysis}

Data was analyzed through open coding. Inductive reasoning was used in organizing the data into themes and categories (White, 2002:82; Maree, 2010:101). After identifying a theme in data using an inductive process, the researchers moved to a more deductive mode to verify it with additional data (Leedy \& Ormrod, 2001: 150). This process involved scrutinizing the data obtained and processed in order to provide information that would make sense to all readers. In this phase data was organized, synthesized and summarized to provide the necessary information and conclusions that relate to the why street kids placed at SOS villages become street kids (Wiersma and Jurs,2000:7; Gibbs 2007:1; Bogdan and Biklen, 2007:175). Thus, the research results obtained are crucial to theory and add to new knowledge.

\subsection{Analysis of data from visual representations}

The visual data was analyzed on different levels using critical interpretive analysis. During the data collection, the participants contributed to the analysis by talking about what they had made, which is regarded as 'external narrative' (Roos, 2008). Then the implicit meanings were analyzed by asking the participants about the deeper meanings attached to the visual representations (Roos, 2012). The visual representations were looked at together with the meanings clarified by the participants. According to Stanczak, (2007) visual representations can reveal meanings and emotions, such as feelings of sadness, happiness, anger and hurt, which may not be revealed in other forms of data.

\section{Ethical Consideration}

The following ethical issues were considered in order to strengthen the trustworthiness of the research project: The principles of basic respect were implemented by first asking for permission to do the study from the SOS village care takers. No participant was coerced to participate. Respect and trust were achieved largely through assuring all participants of the confidentiality of the information they gave. 
The questionnaire did not require any identification of region, school or person to be filled in (Neuman, 2003:126). They were assured that the information gathered would not be used for personal gain, as that would amount to exploitation of the respondents' innocence.Through the covering letter the respondents were also reassured of the confidentiality of the information they provided. Privacy and trust was maintained by holding closed door interviews and there was no disclosure of information to any person except people involved in the project (Neuman, 2003:126).

\section{Trustworthiness of the study}

To ensure validity and reliability, the research project employed a variety of data collection instruments (interviews, the Mmogo method, observations and document analysis) thisis referred to as methodological triangulation (Neuman, 2000:124). In order to gain a deeper understanding of the phenomenon under investigation, special attempts were made to reflect reality from different angles through the process referred to as crystallization.

Table1. Strategies for enhancing the rigor of data through crystallization

\begin{tabular}{|c|c|c|}
\hline Principles & Strategies & Application in the research process \\
\hline $\begin{array}{l}\text { Complex } \\
\text { interpretation }\end{array}$ & Data collection & $\begin{array}{l}\text { Focus group interviews, in- depth interviews and the Mmogo- } \\
\text { Method were triangulated. }\end{array}$ \\
\hline \multirow[t]{2}{*}{ Analysis } & $\begin{array}{l}\text { Mmogo-Method, member } \\
\text { confirmation and in- } \\
\text { depth individual } \\
\text { interviews }\end{array}$ & $\begin{array}{l}\text { Follow-up sessions with participants and discussions with them } \\
\text { clarified the meanings attached to their visual presentations. }\end{array}$ \\
\hline & Variety of methods & $\begin{array}{l}\text { Thematic analysis of the textual data, narrative-oriented inquiry } \\
\text { and the analysis of the visual data derived from the use of Mmogo- } \\
\text { Method enabled the researcher to access rich data to create a } \\
\text { holistic picture of the findings. }\end{array}$ \\
\hline \multirow[t]{2}{*}{$\begin{array}{l}\text { Variety of } \\
\text { presentation }\end{array}$} & Paradigms & $\begin{array}{l}\text { The findings were constructed as themes and patterns to enable the } \\
\text { researcher to interpret the participants' accounts on multiple levels } \\
\text { and thus reveal multiple ways of understanding the research topic. }\end{array}$ \\
\hline & Multiple texts & $\begin{array}{l}\text { After the data has been collected through observational notes and } \\
\text { discussions, the researchers integrated the findings of each } \\
\text { collection strategy and then presented the story in interlinking } \\
\text { manner. }\end{array}$ \\
\hline Reflection & Reflexivity & $\begin{array}{l}\text { The researchers made reflective notes for each part of the research } \\
\text { process in order to keep track of any contributing factors. }\end{array}$ \\
\hline
\end{tabular}

\section{Delimitation of the study}

Moutton (2004) refers to research delimitations as "Transferability," and notes that qualitative research is not mainly concerned with (statistical) generalization, the reason being that all observation is defined by the specific contexts in which they occur. Although the study is supposed to cover the whole district, due to lack of time and resources the researchers covered one SOS Children's Village in Francistown as the sample of the whole district. In order to ensure manageability of the collected data, the research used more multiple choice questions items and a few open- ended response items.

\section{Limitation of the study}

The study is limited to run -away kids as perceived from the psycho-educational point of view. Limitations can be used to reveal weakness attached to the study. The scope of the study was limited because only one SOS children's village was used in this research. Thus, it does not represent the whole population of Botswana SOS villages because it is differentiated by the village facilities, level of proficiency and socio- cultural contexts.Even though the questionnaire included was reliable, due to the capricious nature of human beings, the participants might have decided to withhold the relevant information. 
In view of the above statements, the research was conducted in Francistown district which is located in the North East of Botswana. Therefore, the research findings cannot be generalized to other SOS children`s villages that are located at Serowe and Tlokweng. Secondly, only one research paradigm, which has its own limitations, was employed.

\section{Findings}

Research findings revealed that there are three types of street children, namely street living, street working and street family. Moreover, the concepts street kids, street children and run-away kids were used interchangeably. It was also found from both literature review and empirical research that there is a myriad of factors that trigger vulnerable children placed at SOS villages to become run-away kids. Among other things, when run-away kids were requested to narrate why they ran away from the SOS villages, the following emerged as matters of concern:

One learner said: "At SOS center, I felt like a bird in a cage." The second learner said: "I can make it on my own without the help of anybody. "School drop-out number three said: "The ou ladies at SOS villages are too strict and the school rules are restrictive". In this context "ou lady" is used as slang meaning "old ladies".In response to the question why they choose to live on the street instead of going back to their original homes, one learner said: "You know, I hate my dad, because of him my mother is out there on the street. "From these few responses, it is evident that run-away kids experienced challenges at home which according to them are proportionate or perhaps even more than what they have experienced at the SOS villages. As such, they preferred to be on the streets. One of the mature boys said: "At home, I have one sister with seven children and each one of them has a different father. Four of these children were placed at the same SOS village where I was. Going back home will be just to shoulder the responsibility of my sisters' children."

Judged by what they projected during the interview sessions, more than $50 \%$ of these kids strongly believe that they can make it on their own on the streets far away from the restrictive disciplinary laws at the SOS children's villages. When they were asked to explain why they choose to become homeless and to lead a "hobo-like" life style they immediately indicated that they do not want to go back to their original homes because according to their perceptions, they are on the street becauseof the failure of the very society or their families and /or the community that let them down. Their cry is for personal freedom which was overtly articulated in stronger terms for a unilateral declaration of independence and self reliance.

Further analysis of their voices revealed that sometimes they received bad treatment from some members of the teaching staff at the SOS centers. This made them believe that life on the street is less restrictive. One kid said:"On the street one can opt to work; beg for money or food; one can fend for himself by becoming a street seller.' Unfortunately, they lack knowledge and skills to become survival entrepreneurs. One thing that they are sure of is that like a bird escaping from the cage, they have opted to free themselves from all forms of restraints or confinement that they have experienced at the SOS children's villages or at their original homes. But what they do not know is that their escape is just a way of temporarily avoiding reality. However, we are mindful of the fact that reality is constructed by different groups of people through the operations of language and experience, values, concerns and beliefs. As such, if run-away-kids are escaping in search of reality on the streets, it should be of interest to know that reality is not 'out there' to be objectively and dispassionately observed (Maijs, 2004:4), but it is constructed by experience.

Interview responses from a Guidance counsellor, a nurse and a social worker at the village centre reveal that the learners received the best of the services expected of the centers in terms of shelter, health care and counseling. This response presents a contradiction to the responses of the learners who indicated they had been failed by the SOS villages. In the light of this disagreement, the counselling and health care records of the SOS village were analyzed. Findings confirmed that learners at the SOS were regularly provided with services needed for their survival. Despite the availability of the needed services at the SOS villages, vulnerable learners still escaped to the streets. There is every reason to believe that there are other psychological and socio-cultural pull factors that attract these learners to the street or perhaps the services at the SOS centers are not adequate in addressing their needs. It was also found that once in the street they form a homogenous group which replaces the family as a source of emotional and economic support. For communication purposes, they speak a common street jargon which gives them their uniqueness and special identity. Run-away kids` response to peer influence seems to be largely based on their desire to be liked and accepted by their peer group. Any behavior that advances their belonging to and likability in their group is apt to be repeated by them. 


\section{Recommendations}

It is recommended that in order for the phenomenon of street children to be eliminated or reduced, many things have to change between learners, parents, community, the SOS centers and the way that they deal with problems, for example:

- Parents need to establish a communicative medium that will allow both parties (the child and the parent) to fully communicate with each other regarding any matter. This implies that surviving parents and relatives of learners at SOS centers need to constantly visit these learners in order to build an effective communication relationship necessary to regenerate the trust lost between them. In so doing, there is a possibility that most of the learners will run home rather than to the streets, which is better for them;

- Children need to have a guarantee that they can fully trust their nurses, social workers and counsellors in the SOS canters with anything and that these people only want the best for them. This trust might allow the learners to open up to them on challenges experienced in the SOS villages which might trigger their escape. For such a trust to be established, employees in the SOS are supposed to be experts in their field of specializations. In a nut shell, it is recommended that the services to these learners be improved to contain some of the pull factors that draw them to the street.

- The strategy of using a peer to modify learner behavior can be applied to eradicate the run-away behavior of the learners. Peer influence is a two edged sword. On the one hand, it can lead learners with weak self-control to perform risky and undesirable behaviors like escaping from SOS centers. On the other hand, it can serve to moderate undesirable behavior (Sousa, 2009:116).

- The curriculum of the SOS center needs to be revisited and modified to include content of self-management, social and survival skills in the streets. The reason is because at present, since learners cannot be prevented from running to the streets, there is a need to prepare them for the streets so that they don't become vulnerable. In so doing, they will be well equipped to face the dangers in the street and how to survive.They should also take into consideration the need to be in the SOS centers which is a place of safety. This recommendation is supported by Colvin (2008:58) who states that the appropriateness of curriculum would encourage learners to avoid escaping from their learning centers. Teaching self-management skills to street kids could equip them to take charge of their life. Since they perceive the world differently, they need selfmanagement skills that would steer them to comply with the norms of the society while they are out in the streets (Colvin, 2008:62). This reduces their level of vulnerability.

\section{Recommendations for future research}

Future research would be well placed to use more than one research approach, and covering the whole of Botswana in order to produce findings that could be generalized in other areas where similar SOS children`s villages are located.

\section{Concluding remarks}

Following from the preceding discussion, it has become clear that the study was conducted against the backdrop of Botswana Children`s Act 28 of 2004 which promulgated that every Motswana child should be cared for and protected against harm. It was against this backdrop that the research project investigated why vulnerable learners placed at the SOS villages, where they are supposed to be protected and happy, run away to the streets where they become exposed to all forms of unfavorable living conditions. Therefore, conceptual literature relating to contributory factors influencing vulnerable learners placed at SOS villages to become street children was thoroughly reviewed. Furthermore, empirical research that focused on factors that influence vulnerable learners at SOS villages was conducted. What emerged is that vulnerable learners were strategically placed at a monitored shelter. Surprisingly, they opted to escape.This is an indication that perhaps there are hidden, deep rooted psychosociological and / or psycho-educational problems that need to be revealed by future researches.

\section{References}

Bell, J. 2000 Doing Your Research Project: A guide for first - time researchers in education, health \& social sciences $\left(3^{\text {rd }} \mathrm{Ed}\right)$.New York: Open University Press.

Bell, J. 2005. Doing your research project. ( ${ }^{\text {th }}$ Ed). New York: Open University Press.

Berk, L.A. 2006.Child Development ( $7^{\text {th }}$ Ed).Pearson/Allyn and Bacon: Canada. 
Best, J. W. and Khan, J. V. 2006.Research in Education.( $3^{\text {rd Ed. }) ~ H o n g ~ K o n g: ~ P e a r s o n ~ E d u c a t i o n, ~ I n c . ~}$ BOTSWANA 2004. Children's Act 28 of 2004.Gaborone: Government Printer.

BOTSWANA 2005.Children in need of care regulations 28of 2005. Gaborone: Government Printer.

Briggs, A.R.J. \& Coleman, M. 2007. Research methods in Education Leadership and Management $\left(2^{\text {nd }}\right.$ Ed). London: Sage Publications

Conboy, B. T., Sommerville, J. A., \& Kuhl, P. K. 2008. Cognitive Control Factors in Speech Perception at 11 Months. Developmental Psychology. London: Pearson.

Cottrell, H. 2003. The Study Skills Hand book. ( $\left.2^{\text {nd }} E d\right)$ : Hound mills. Palgrave Macmillan.

Creswell, J.W. 2009. Research design: Qualitative, Quantitative, and Mixed Methods Approach ( $3^{\text {rd } E d) . ~ L o s ~}$ Angels: Sage.

Creswell, J.W., Clark, P.V.L. 2007. Designing and conducting research in education. Los

Devos, A.S. (2002). Research at grassroots Pretoria: Van Schaik Publishers.

Gibbs, G. (2007). Analyzing Qualitative Data. London: SEGA Publication. Ltd.

Jonson, B. Thesaurus of the English Language. $\left(2^{\text {nd }} E d\right)$.Harper CollinsPublishers.PrincetoUniversity.

Komane, K. 2011. SOS Children's Village International. Retrieved from http//www.SOS.org.bw on the 26/06/.

Leedy, P. D \& Ormrod, J. E. 2005. Practical Research: Planning and Design. New Jersey: Pearson Prentince Hall.

Maree, K. 2010. First steps in Research ( $4^{\text {th }}$ Ed). Pretoria: Van Schaik Publishers.

Marvasti, A. B. 2004. Qualitative Research in Sociology. London: Sage Publications.

McMillan, J. H. \& Schumacher, S. 2001. Research in Education: A Conceptual Introduction (5 ${ }^{\text {th }}$ Ed). New Jersey: London.

Monobe, R. J. 2005. Basic Classroom Research (EDT12). Mafikeng: North WestUniversity.

Mouton, J. 2005. How to succeed in your Master's and Doctoral studies. Pretoria: Van Schaik.

Swift, T. 2009 Heritage Dictionary The American Heritage Dictionary of the English Language. $\left(4^{\text {th }} \mathrm{Ed}\right)$ Houghton: Mifflin Company.

Neuman, W.L. 2003. Social research methods: Qualitative and Quantitative approaches. Boston: Pearson Education.

Trochim,W. 2006 Social Research Methods. Retrieved from http:/www.social research methods.net on the $26 / 06 / 12$.

Vogel, H.M. 2001. Educare, Volume 30. Issue 1. South African Journal of Higher Education.

Wallen, N.E. and Fraenkel, J.R. 2001. Educational Research; a guide to the process, Lawrence Erlbaum Associates: New Jersey.

Watts, D. SOS Children's Village. Retrieved from http//www.SOS.childrensvillage.org/where- on the 26/06/.

Welman, J.C .Kruger, S. J. \& Michel 2005. Research Methodology ( $3^{\text {rd }}$ Ed). Cape Town.

Wiersma, W. and Jurs, S.G. 2005.Research Methods in Education, London: Pearson, Education, Inc.

White, C. J. 2002. Revised methods and techniques. New York: Harper Collins College. 